Roberto Morabito*,

Dipartimento di Sostenibilità dei Sistemi Produttivi e Territoriali, ENEA - Agenzia nazionale per le nuove tecnologie, I'energia e lo sviluppo economico sostenibile, Roma, Italia

* Con/with Claudia Brunori, Grazia Barberio, Carolina Innella, Mario Jorizzo, Flavio Scrucca, Chiara Cardenia, Elisabetta Salvatori, Marco Tammaro

Il Green Deal Europeo pone al centro della ripresa la transizione digitale e la decarbonizzazione (European Commission, 2019a). Parte integrante di questa strategia è il nuovo piano di azione per l'economia circolare, strumento chiave per la resilienza e la rigenerazione che si rivolge principalmente alle città e alle regioni, i maggiori produttori di impronte ambientali e, pertanto, con un alto potenziale di sviluppo sostenibile globale (European Commission, 2019b).

Secondo il Programma delle Nazioni Unite per l'ambiente, le città svolgono un ruolo di primo piano nell'attuazione di un Green New Deal poiché ad oggi sono responsabili di circa il 75\% delle emissioni mondiali di gas ad effetto serra, GHG.

Passare a un'economia circolare significa pensare non solo alla dimensione fisica delle risorse ma anche ai comportamenti umani che favoriscono approcci e modalità circolari. Tutto ciò può essere supportato e concretamente realizzato solo creando comunità urbane resilienti attraverso la condivisione, la comproprietà e la co-gestione delle risorse urbane e territoriali. Questo approccio si basa necessariamente su un cambiamento sistemico che necessita di dinamiche integrate e innovative per poter raggiungere un ciclo trasformativo di autosufficienza su scala di medio termine. Le città sono il luogo principale di questa trasformazione, in cui la circolarità deve essere parte non solo dell'economia ma della società stessa e del sistema cittadino nel suo complesso, coinvolgendo i cittadini e le loro pratiche.

Il Dipartimento di Sostenibilità dei Sistemi Produttivi e Territoriali (SSPT) di ENEA si occupa da molti anni di economia circo-

\section{THE CIRCULAR \\ ECONOMY \\ TRANSITION IN \\ URBAN AREAS AND \\ COMMUNITIES: \\ ENEA'S APPROACH}

Introduction

The European Green Deal puts the digital transition and decarbonisation at the heart of the Covid-19 recovery (European Commission, 2019a).

An integral part of this strategy is the New Circular Economy Action Plan, a key instrument for resilience and regeneration that primarily targets cities and regions, being the main producers of environmental footprints, with a high potential to evolve global sustainable development (European Commission, 2019b).

According to the United Nations Environment Programme, cities play a leading role in implementing a Green New Deal as today they account for about $75 \%$ of the world's GHG emissions.

Moving to a circular economy would mean considering not only the physical dimension of waste and resources,

lare e di sviluppo urbano e territoriale sostenibile. Ha sviluppato progetti, tecnologie, strumenti e approcci sistemici e transdisciplinari per innescare e accompagnare questo processo di transizione. Approcci con cui è stata elaborata la nuova Strategic Research and Innovation Agenda, SRIA, per l'economia circolare, nell'ambito della quale le aree urbane rappresentano una delle sfide principali (Cicerone, 2020).

Questi stessi approcci, attraverso un dialogo multi-stakeholder, sono alla base dell'Italian Circular Economy Stakeholder Platform, ICESP ${ }^{1}$, creata quale interfaccia nazionale della analoga piattaforma europea ECESP, che opera con l'obiettivo di supportare il processo di transizione circolare e rappresenta il punto di convergenza nazionale su iniziative, esperienze, criticità e prospettive che l'Italia vuole e può rappresentare in Europa.

La realtà delle aree metropolitane è pronta per realizzare processi di innovazione, ma anche su aree più piccole è importante dare indicazioni che siano replicabili. In questo contesto il contributo presenta esempi di innovazione a bassa intensità tecnologica implementabili su piccole comunità, seguendo un approccio integrato e soprattutto collaborativo, attraverso il coinvolgimento sul territorio. Si tratta di alcune esperienze progettuali che pongono in particolare evidenza il dialogo multi-stakeholder e la partecipazione della società civile, condizione necessaria per poter affrontare il processo di transizione e raggiungere gli obiettivi di neutralità climatica.

In conclusione si propone una breve riflessione sul grande potenziale delle Nature-based Solutions (NbS) nei processi di ri-

but also behaviours that foster circular practices.

In principle, the circular economy aims to close loops, extend the life cycle of goods and implement business models for a circular and climate-neutral consumption. However, all this can be supported by creating resilient communities through sharing, co-owning and managing cities' resources.

This approach is based on a systemic change that implements self-sustaining dynamics to reach a mid-term scale transformative cycle.

Cities will be the main target for this transformation, in which circularity can be not only be part of the economy but also of society and of the city system as a whole, involving its citizens and their practices.

ENEA's Department for Sustainability has been dealing with the circular economy and territorial sustainable development for a long time, having implemented projects, technologies, tools and systemic and transdisciplinary approaches triggering and accompanying the transition process.

The same approach is the background of the new SRIA for a circular economy (CICERONE, 2020), in which urban areas are one of the main challenges, and also of the Italian Circular Economy Stakeholder Platform, ICESP ${ }^{1}$, the mirror platform of the European ECESP, which aims to foster the Italian approach to the circular economy.

ICESP was founded as a forum bringing together initiatives, experiences, criticalities and perspectives that Italy represents in Europe, fostering circularity in Italy with specific actions. Metropolitan areas are ready to carry out innovation processes, but also in smaller areas it is important to give indications that can be replicated. In this 
generazione urbana, su cui ENEA sta lavorando in termini di nuova progettualità.

\section{Progetto NETWAP: gestione sostenibile dei rifiuti nelle piccole comunità}

Le piccole realtà territoriali devono generalmente affrontare le stesse sfide nella gestione dei rifiuti, sfide legate alla presenza ridotta o alla totale assenza di impianti di trattamento e alla conseguente necessità di trasporto (spesso a grande distanza) degli stessi, con relativi maggiori costi ed impatti ambientali. Il progetto NETWAP, NETwork of small in situ WAste Prevention and management initiatives ${ }^{2}$, è finalizzato all'individuazione di soluzioni per una gestione sostenibile dei rifiuti in tali contesti, focalizzando l'attenzione anche su piccole comunità in aree di interesse turistico e/o costiere, per le quali sono presenti ulteriori criticità comuni, fluttuazioni stagionali di quantità prodotte (dovute ai flussi turistici) e presenza di particolari categorie merceologiche al loro interno non propriamente trattate, come la frazione organica e i rifiuti marini. Le soluzioni proposte ai fini di una gestione sostenibile e "collaborativa" (coinvolgimento diretto dei vari stakeholder territoriali) dei rifiuti nelle piccole comunità di riferimento sono costituite dal compostaggio su piccola scala e dalla messa a punto di procedure specifiche funzionali al recupero/riciclo delle plastiche contenute nei rifiuti spiaggiati. Nell'ambito del compostaggio su piccola scala, sono individuate tre soluzioni di gestione caratterizzate da differenti modalità di funzionamento e coinvolgimento diretto crescente degli stakeholder:

il compostaggio locale, molto simile ad una gestione convenzionale in cui i cittadini conferiscono ad un impianto

context, the purpose of this paper is to propose low-intensity tech-innovation examples that can be implemented in small communities through an integrated and collaborative approach, and with local involvement.

The following paragraphs describe some of ENEA's projects in this regard, highlighting the multi-stakeholder dialogue and the involvement of the civil society as the main factors to face the transition process and to achieve climate neutrality objectives.

In the last paragraph, there is a brief description about the great potential of Nature-based Solutions (NbS) in urban regeneration processes, for which ENEA is developing new activities and projects.

NETWAP project: sustainable waste management in small communities

In general, small communities have to face common challenges in waste management which are related to the lack of infrastructure (limited or missing treatment plants) and to the consequent long-distance shipping/ transportation of waste, with higher costs and environmental impacts. The NETWAP project ${ }^{2}$ is focused on local solutions for sustainable waste collection/treatment, also for those territories (tourist/coastal areas, islands) characterised by other relevant issues, such as seasonal fluctuation in waste generation (due to tourist flows) with the presence of specific waste categories not properly treated, e.g. bio-waste and marine litter.

The proposed solutions for sustainable waste collection/treatment with the active engagement of relevant stakeholders of the reference territory regard smallscale composting and specific recovery procedures of marine plastic waste. gestito da terzi (amministrazione, municipalizzata, ecc.), senza un coinvolgimento diretto vero e proprio nella gestione del rifiuto (con le sole differenze di trattamento a livello locale e di quantità trattate);

- il compostaggio di comunità, in cui i produttori del rifiuto (più utenze domestiche e non) sono anche gestori (più soggetti, non necessariamente tutti, organizzati in un consorzio o associazione) e utilizzatori del compost prodotto, con un livello di coinvolgimento maggiore;

- l'auto-compostaggio, effettuato da utenze domestiche o assimilabili (ristoranti, alberghi, campeggi, ecc.) ai fini dell'utilizzo in sito del compost, che prevede quindi una gestione diretta e consapevole da parte del soggetto coinvolto.

Per quanto riguarda invece le azioni funzionali al recupero e riciclaggio dei rifiuti plastici spiaggiati, la proposta progettuale riguarda la messa a punto di un opportuno schema di gestione (raccolta, lavaggio, selezione e trattamento per recupero di materia/energia) che coinvolga direttamente i diversi stakeholder locali (amministrazione, associazioni, cittadini, ecc.) e consente di evitarne lo smaltimento come rifiuto indifferenziato (Fig. 1). Ad oggi, sono stati sviluppati tutti i documenti tecnici necessari alle amministrazioni e agli altri stakeholder per implementare il compostaggio su piccola scala. Le relative infrastrutture sono in fase di completamento o avviamento. Allo stesso tempo, sono stati sperimentati i processi di lavaggio e trattamento (estrusione filamenti) per il riciclo di specifiche plastiche (reti per mitilicoltura e molluschi) derivanti dai rifiuti spiaggiati, nonché l'utilizzo di un mix di plastiche non selezionate per la produzione di olio combustibile (attraverso pirolisi).

Per quanto le attività progettuali siano attualmente in corso e,
In the framework of small-scale composting, three management solutions characterised by different modes of operation and by an increasing direct involvement of stakeholders are identified:

- Local composting, very similar to a conventional management system (with the exceptions of the treatment at local level and the treated quantities) in which citizens deliver to a composting plant managed by other parties (administration, municipality, etc.), without a real direct involvement in waste management; Community composting, i.e. a composting-at-source technique so that bio-waste generated by several subjects (individuals, families or other generators) is jointly treated in a single module within a common purpose-set area and the compost is used directly by the (or some of the) producers (associated under a common organisation);

Auto-composting, i.e. compost production from the treatment of bio-waste generated by individual subjects (restaurants, campsites, hotels, etc. or households) and its use in their own backyards, with all the know-how for its management. Regarding plastic marine litter, the project proposal concerns the development of an appropriate management scheme (collection, washing, selection and treatment for material/energy recovery) that directly involves the various local stakeholders (administration, associations, citizens, etc.) and allows the disposal of the plastics as unsorted waste to be avoided (Fig. 1).

The present project status is that all the technical documents necessary for administrations and other stakeholders to implement small-scale composting 
quindi, le evidenze sull'effettiva sostenibilità di un sistema di gestione locale e collaborativo dei rifiuti nelle piccole comunità solo parziali, la rilevanza ai fini della transizione verso la circolarità di un approccio integrato che coinvolga direttamente i diversi attori del territorio al fine di rendere i rifiuti una risorsa quanto più possibile gestita e sfruttata localmente, appare evidente già dai primi risultati ottenuti.

\section{Progetto INNOWEE}

Il progetto InnoWEEE, Innovative WEEE traceability and collection system and geo-interoperability of WEEE data ${ }^{3}$, finanziato da EIT, European Institute of Innovation and Technology, Climate-KIC, Knowledge Innovation Community, a partire dal 2018, si propone di creare un modello innovativo e replicabile per la gestione della raccolta dei Rifiuti da Apparecchiature Elettriche ed Elettroniche, RAEE, e per incentivarne recupero, riuso e riciclaggio, in linea con i principi delleconomia circolare. Oltre ad ENEA, sono coinvolti Dedagroup Public Services, ERION, Fondazione Bruno Kessler e Betterpoints. Il progetto ha visto lo sviluppo di tre pilota in tre diverse città: Rovereto, Cava de' Tirreni e Bath (UK). In ognuna si sono implementate diverse attività per raggiungere quelli che erano gli obiettivi del progetto.

Per InnoWEEE ENEA ha progettato lo Smart Bin, (Fig. 2), un contenitore smart per la raccolta intelligente dei RAEE, alimentato a batteria, di dimensioni di circa $170 \times 50 \times 60 \mathrm{~cm}$, dunque di facile collocazione e svuotamento. Lo smart bin ha un sistema di riconoscimento tale che si apre al conferimento, solo se l'utente si fa riconoscere tramite tessera sanitaria ed è dotato di sensori di riempimento che, collegati alla piattaforma web, forniscono in tempo reale e in autonomia informazioni su quantità e tipo di RAEE raccolti. Lo smart bin, inoltre, è in grado di rilasciare uno scontrino "ecologico" che, in base al rifiuto conferito, fornisce al cittadino informazioni sulle emissioni di $\mathrm{CO}_{2}$ evitate grazie al corretto smaltimento e che gli consente di rientrare in un programma di premialità per ottenere sconti presso esercizi commerciali convenzionati. Oltre alla realizzazione, ENEA ha gestito anche la fase di sperimentazione degli smart bin, attualmente in corso nell'area pilota del Comune di Cava de' Tirreni (SA), con l'installazione di 4 smart bin sul territorio cittadino in punti strategici, quali il centro commerciale, il municipio, l'isola ecologica e 3 scuole superiori a rotazione. Attraverso una diffusa campagna di sensibilizzazione della cittadinanza, ENEA ha contribuito ad aumentare la raccolta dei RAEE, avviandoli verso una catena di valorizzazione. Inoltre nell'ambito dello stesso progetto pilota si è provveduto a implementare un sistema di raccolta delle apparecchiature elettriche ed elettroniche, AEE, ancora funzionanti ma non più utilizzati dai propri proprietari, per dargli una seconda vita ed allontanare il momento in cui diventano RAEE.

\section{Progetto ES-PA Pon Governance: Matera e Lampedusa}

L'ENEA, nell'ambito del progetto ES-PA PON Governance 2014-20, sta sviluppando una serie di attività con lo scopo di avviare alcune traiettorie di sviluppo sostenibile energetico-ambientale, quali la rigenerazione urbana, l'uso efficiente delle risorse, il turismo sostenibile e di aumentare le capacità progettuali e realizzative delle Regioni ed in particolare degli Enti Locali nell'affrontare problematiche territoriali sui temi dello sviluppo economico, ambientale e sociale.

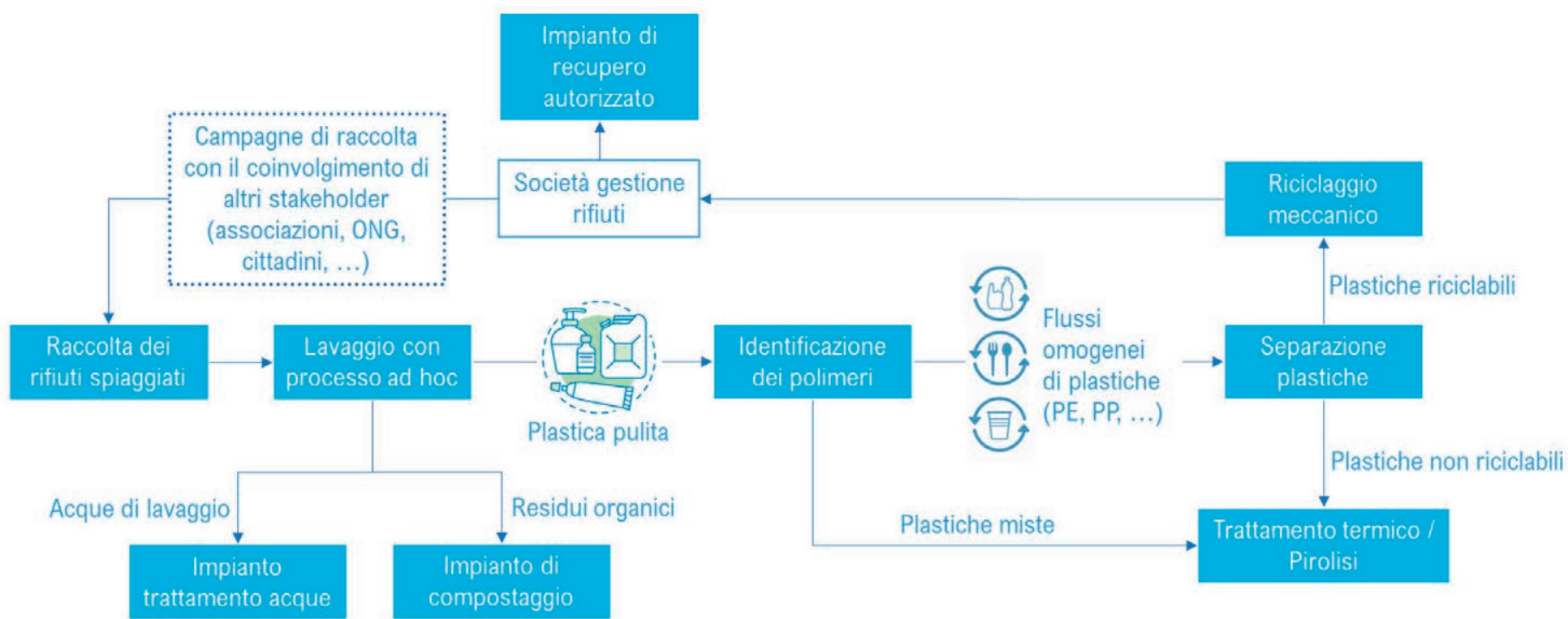


Le strategie di transizione verso un'economia e una società a basse emissioni di carbonio hanno messo in evidenza la stretta interdipendenza tra la sostenibilità energetica e quella ambientale. L'esempio più evidente è quello dell'economia circolare quale modello integrato di azioni come, tra le altre, quelle per l'uso efficiente delle risorse energetiche e materiali. Tali azioni interessano non solo le filiere produttive ma anche i processi di consumo, le relazioni tra i diversi soggetti (imprese, consumatori, famiglie, istituzioni) e quindi la governance territoriale.

Gli interventi che si stanno realizzando riguardano due aree significative e rappresentative di tipologie territoriali diverse:

- l'area territoriale di Matera, rappresentativa di aree rilevanti di periferia interna;

- l'isola di Lampedusa, rappresentativa di aree remote e di isole minori.

Per la sua ubicazione, la sua cultura e il suo sviluppo, Matera è un sito di particolare interesse.

Il progetto prevede la realizzazione di attività in grado di attuare linee di sviluppo sostenibile coerenti con la storia del territorio e, al contempo, replicabili.

Tali iniziative, insieme al coinvolgimento della P.A. e degli stakeholder locali, vogliono essere un passo significativo "verso il futuro", per rendere Matera un polo dell'innovazione urbana sostenibile da un punto di vista energetico-ambientale, una sorta di "Paradigma Urbano" per la sostenibilità ambientale nell'Area Mediterranea.

Le azioni sino ad ora individuate, di concerto con i principali stakeholder locali, mirano ad attuare iniziative esemplari ad alto indice di replicabilità per soluzioni innovative di agricoltura urbana ad alta efficienza dell'uso di risorse, per la preservazione di

have been developed and the related infrastructures are in the completion or start-up phase. The project activities are currently ongoing and, therefore, results regarding the effective sustainability of a local and collaborative waste management system in small communities are only partial. At the same time, washing and treatment processes (filament extrusion) were tested for the recycling of specific plastics (mussel nets and shellfish) derived from beached waste, as well as the use of a mix of unselected plastics for the production of fuel oil (through pyrolysis). In any case, in view of the transition towards circularity, the relevance of an integrated approach directly involving the various actors of the territory in order to make waste a locally managed and exploited resource is evident from the preliminary project results.

\section{INNOWEE project}

The InnoWEEE project, Innovative WEEE traceability and collection system and geo-interoperability of WEEE data ${ }^{3}$, funded by EIT (European Institute of Innovation and Technology) and Climate-KIC (Knowledge Innovation Community) in 2018, aims to develop and implement an innovative and replicable model for the collection of WEEE (Waste from Electrical and Electronic Equipment) and their recovery, reuse and recycling, according to the principles of the circular economy. In addition to ENEA, Dedagroup Public Services, ERION, Fondazione Bruno Kessler and Betterpoints are also involved. The InnoWEEE project is structured around three pilot areas, namely Bath (UK), Rovereto (Northern Italy) and Cava de' Tirreni (Southern Italy), where different activities have been

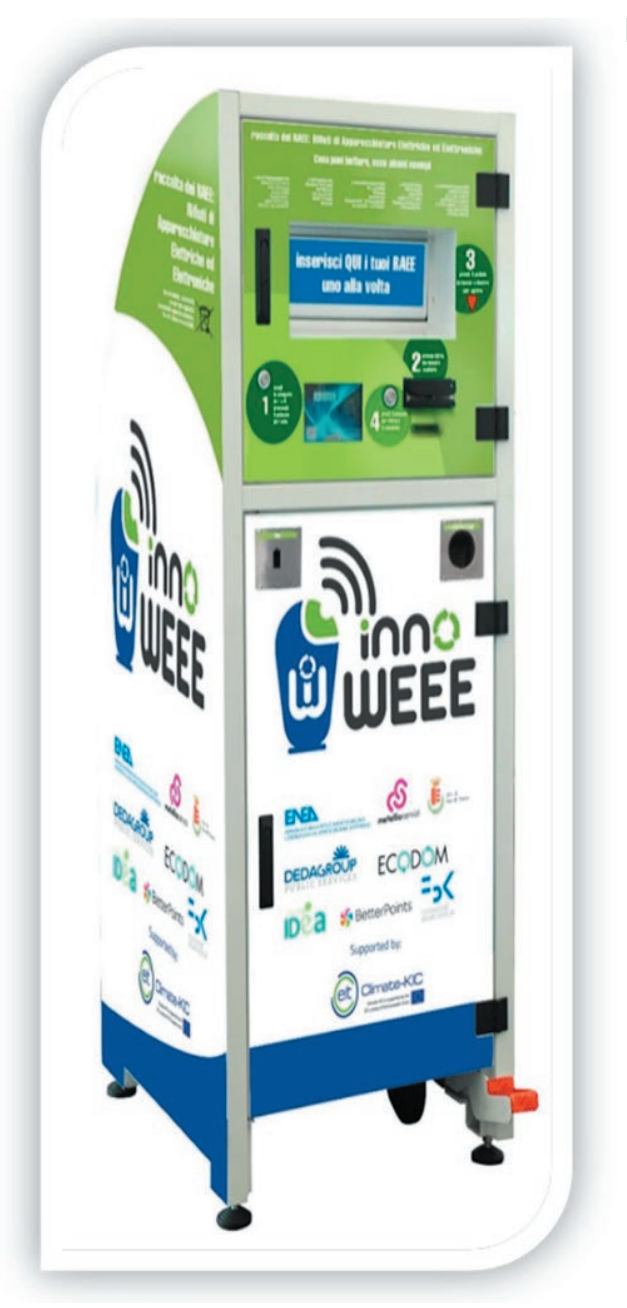

beni artistici e architettonici con tecniche innovative e naturali e per l'implementazione dei principi dell'economia circolare a livello urbano.

In particolare, quest'ultima azione, nata da pregresse e positive esperienze progettuali (Cappellaro et al., 2018; Cappellaro et al., proposed to achieve the goal of the project.

In the framework of this project, a smart bin was designed by ENEA for the smart collection of WEEE. The smart bin (Fig. 2) is battery powered and its size $(170 \times 50 \times 60 \mathrm{~cm})$ is suitable for easy positioning and emptying. Equipped with management software and an array of sensors, the smart bin is capable of collecting WEEE if it recognises the citizen who is disposing of his/her WEEE by means of their health card, as well as sensing the quality and quantity of the deposited waste, transmitting real-time data to a web platform. Furthermore, for each delivery event, the smart bin emits an "ecological" receipt, providing information about the $\mathrm{CO}_{2}$ emissions that are avoided thanks to the correct disposal of the WEEE. By means of this receipt, each smart citizen can join a rewarding system and obtain a discount voucher in affiliated shops.

ENEA is in charge not only of the realisation of the smart bin, but also of the implementation of the project in the pilot area in Cava de' Tirreni (SA), where 4 smart bins are located as collection points in key sites throughout the town, namely the municipality, the mall, the main curbside drop-off and three different secondary schools in rotation. Through a widespread awareness-raising campaign, ENEA is contributing to increase the amount of collected WEEE and to put into practice resource-efficient processes for the collected devices. Within the pilot area, a collection system for used EEE (Electrical and Electronic Equipment) is also available for implementing environmentally friendly supply chains through refurbishment and remanufacturing processes. 
2019), si inserisce nella Linea di intervento 3.2 "Progetto Integrato Territoriale" in cui è stato creato un Living Lab sull'economia circolare che vede coinvolti gli studenti dell'Istituto di Istruzione Secondaria Pitagora nella città di Policoro (MT), attività organizzata in 3 annualità scolastiche (dal 2019 al 2022). L'obiettivo principale è quello di creare uno spazio temporaneo, aperto e creativo per affrontare problemi pratici e per sperimentare idee e le soluzioni innovative, migliorando i processi di impegno sociale ed empowerment. Le idee possono, quindi, essere testate e valutate in un contesto di vita reale a livello micro (scuola), per poter poi innescare processi di transizione anche a livello macro (città/quartiere). Il percorso è iniziato con un ciclo di seminari di tipo informativo-formativo rivolto alla comunità di studenti e docenti costruendo un primo nucleo di comunità sensibilizzata alle tematiche ambientali e di economia circolare (Community School sull'Economia Circolare).

La Community School evolve poi in un Living Lab sulleconomia circolare, con l'obiettivo di co-progettare e realizzare alcuni modelli di economia circolare in ambito scolastico e presentarli alla comunità urbana del territorio, per coinvolgerla e per innescare processi di transizione su scala più ampia. La scuola diventa così fulcro e promotrice di processi di cultura sostenibile e di sviluppo verso l'innovazione tecnologica di rivalorizzazione ambientale. Lampedusa rappresenta un esempio di isole minori mediterranee e di aree isolate, è sede dell'Area Marina Protetta "Isole Pelagie". A partire dall'Osservatorio Climatico ENEA, operativo sull'isola dal 1997, il progetto ha lo scopo di coinvolgere funzionari della Pubblica Amministrazione ed un ampio pubblico sui temi ambientali ed in particolare sul cambiamento climatico e sulla valorizzazione del capitale naturale.

\section{ES-PA PON Governance project: Ma-} tera and Lampedusa

ENEA, as part of the PON Governance 2014-20 ES-PA project, is implementing different projects with two main goals: to implement some trajectories of sustainable energy-environmental development, such as urban regeneration, efficient use of resources and sustainable tourism, and to increase the planning and implementation capacities of the local public administration in addressing territorial problems on issues of economic, environmental and social development.

Transition strategies towards a lowcarbon society and economy have highlighted the close interdependence between energy and environmental sustainability. The most obvious example is the integrated model of a circular economy which includes the efficient use of energy and material resources.

Inoltre, si intende valorizzare ulteriormente l'infrastruttura ENEA e favorirne l'accesso anche nell'ambito di Summer School dedicate all'alta formazione (diretta a giovani ricercatori) e all'aggiornamento professionale tecnico/scientifico, sull'esempio delle Large Scale Facilities.

Le esperienze di formazione (es. dirette a funzionari, insegnanti, addetti Aree Protette, oltre che ai ricercatori) e di divulgazione scientifica consentiranno lo sviluppo di forme di turismo alternativo e destagionalizzato che, favorendo una maggiore consapevolezza ambientale, potranno essere replicate in altri contesti geografici.

Il progetto integrato quindi caratterizzerà fortemente Lampedusa, portando alla creazione di un "brand" ambientale e promuovendo l'isola quale punto di riferimento mediterraneo ed internazionale per un turismo scientifico.

\section{Soluzioni Basate sulla Natura per le città circolari}

Nei processi di transizione circolare delle città, un ruolo fondamentale è svolto dall'utilizzo delle Nature-based Solutions, NbS, definite dalla commissione europea come soluzioni ispirate alla natura e da essa supportate, che siano convenienti, forniscano al contempo benefici ambientali, sociali ed economici e contribuiscano a creare resilienza (European Commission, 2021). Le NbS sono elementi naturali multifunzionali, che garantiscono la fornitura di servizi ecosistemici, aumentando il benessere e la rigenerazione delle aree urbane e favorendo l'adattamento al cambiamento climatico. Esse forniscono inoltre co-benefici ricreativi e culturali, contribuiscono a ridurre i consumi energetici degli edifici e possono integrare le tecnologie tradizionali, anche nei processi di transizione

are consistent with the history of the territory and, at the same time, replicable.

These initiatives, together with the involvement of the P.A. and local stakeholders, want to be a significant step "towards the future", to make Matera a "case study" of sustainable urban innovation from an energy-environmental point of view, a sort of "urban paradigm" for environmental sustainability in the Mediterranean Area.

The actions identified so far, in concert with the main local stakeholders, aim to implement exemplary initiatives with a high replicability index for innovative urban agriculture solutions with high efficiency in the use of resources, for the preservation of artistic and architectural heritage with innovative and natural techniques, and for the implementation of the principles of the circular economy at the urban level.
In particular, this last action, emerging from previous and positive design experiences (Cappellaro et al., 2018; Cappellaro et al., 2019), is part of the line of intervention 3.2 "Integrated Territorial Project". The core of the project is the creation of a circular economy Living Lab (LL) which involves the students of the secondary education institute "Pitagora", in the city of Policoro in the province of $\mathrm{Ma}$ tera, with different activities organised during three school terms (from 2019 to 2022). The main goal of the $\mathrm{LL}$ is to create a temporary, open and creative space to face practical problems and to test innovative ideas and solutions, improving the processes of social engagement and empowerment. Therefore, the ideas can be tested and evaluated in a real-life context at the micro level (school), in order to then also trigger transition processes 
circolare. Ne sono esempio le soluzioni integrate per il recupero e il riciclo delle acque a scala di edificio (es. coperture e pareti verdi) e di quartiere (aree ad allagamento controllato, fasce filtro, pavimentazioni e aree permeabili), sperimentate da ENEA nel progetto GST4Water ${ }^{4}$

Al contempo, le NbS supportano la biodiversità urbana, aumentando la connettività ecologica sia all'interno della città che con le aree naturali ed agricole circostanti, come evidenziato dalle ricerche ENEA nell'ambito del progetto MaGICLandscapes 5 . È fondamentale a tal proposito l'utilizzo di criteri ecologici per la realizzazione delle NbS: nel progetto ES-PA, ENEA ha prodotto Linee guida e un tool operativo ${ }^{6}$ per realizzare e gestire in modo sostenibile le Infrastrutture Verdi urbane, utilizzando specie della Flora d'Italia.

Infine, $\mathrm{NbS}$ innovative sono sempre più spesso applicate per il restauro sostenibile dei beni culturali, come sperimentato a Matera in ES-PA, oltre che per il controllo della qualità dell'aria indoor in ambienti museali (Salvatori et al., 2020).

Le NbS svolgono pertanto un ruolo chiave nel garantire la sostenibilità urbana in uno scenario di cambiamento globale, come auspicato dall'SDG 11 dell'Agenda 2030. La creazione di un ambiente urbano sano è ormai diventata una priorità, come evidenziato in maniera drammatica dalla pandemia da COVID-19, e le $\mathrm{NbS}$ rappresentano uno strumento innovativo per rispondere alle principali sfide della società in questo senso. Tuttavia, è necessario rendere operativo il concetto di $\mathrm{NbS}$, integrandolo nei quadri politici esistenti, nonché con gli altri strumenti della transizione circolare. Le attività progettuali future dovranno prevedere il coinvolgimento attivo di stakeholder e cittadini tramite processi decisionali partecipativi, attraverso cui evidenziare

at the meso and macro level (neighborhood and city). The path started with a cycle of informative training seminars directed at the community of students and teachers, to build a first nucleus of a community sensitised to environmental issues and the circular economy (community school on circular economy). Then, the community school evolves into a circular economy LL, with the aim to co-design and implement different models of a circular economy in the school environment and to present them to the urban community of the territory, and finally, to involve the urban community and to trigger transition processes on a larger scale. The school thus becomes the fulcrum and promoter of sustainable culture and development processes towards technological innovation of environmental enhancement.

benefici, costi, incertezze e compromessi delle NbS in contesti specifici. Ciò rappresenta un presupposto essenziale per la loro implementazione in città e territori, a sostegno di uneconomia circolare efficiente e competitiva.

\author{
NOTE \\ ${ }^{1}$ ICESP website: www.icesp.it \\ ${ }^{2}$ Fonte: https://www.italy-croatia.eu/web/netwap \\ ${ }^{3}$ Fonte: http://www.innoweee.eu/it \\ ${ }^{4}$ Fonte: https://www.gst4water.it/index.php/il-progetto-offcanvas-new \\ ${ }^{5}$ Fonte: https://www.interreg-central.eu/Content.Node/MaGICLandscapes. \\ html \\ ${ }^{6}$ Fonte: https://anthosart.florintesa.it/
}

\title{
REFERENCES
}

Cappellaro, F., Cutaia, L., Innella, C., Meloni, C., Pentassuglia, R. and Porretto, V. (2019), "Investigating circular economy urban practices in Centocelle, Rome district”, Environmental Engineering and Management Journal, Vol. 18, n. 10, pp. 2145-2153.

Cappellaro, F., Cutaia, L., Innella, C., Pentassuglia, R. and Porretto, V. (2018), "Co-design of circular economy model adopting Urban Living Lab approach", Book of Papers of the 24th International Sustainable Development Research Society Conference. Action for a Sustainable World: from theory to practice, Messina, Italy, June 13-15, pp 776-786.

Cicerone (2020), "Strategic research and innovation agenda on circular economy", available at: https://cicerone-h2020.eu/wp-content/uploads/2021/03/CICERONE-SRIA-2021.pdf .

European Commission (2019a), "Il Green Deal europeo, 640 final", available at: https://ec.europa.eu/info/strategy/priorities-2019-2024/europeangreen-deal_en.

ers) and scientific dissemination will allow the development of alternative and seasonally adjusted forms of tourism which, favouring greater environmental awareness, can be replicated in other contexts.

The integrated project will, therefore, strongly characterise Lampedusa, leading to the creation of an environmental "brand" and promoting the island as a Mediterranean and international reference point for scientific tourism.

\section{of natural capital.}

In addition, it is intended to further enhance the ENEA infrastructure and facilitate access in the context of summer schools dedicated to higher education (aimed at young researchers) and professional technical/scientific updates, following the example of the large-scale Facilities.

The training experiences (e.g. directed to public officials, teachers, protected area employees, as well as to research- ience (European Commission, 2021). $\mathrm{NbS}$ are natural, multifunctional elements that provide ecosystem services, thus supporting human wellbeing, favouring the regeneration of urban areas as well as climate change adaptation. They also provide recreational and cultural benefits, help reduce the energy consumption of buildings, and can also integrate traditional "grey" technologies in circular transition processes. Examples are the integrated solutions for water recovery and recycling at the building (e.g. green roofs and walls) and neighbourhood (controlled flooding areas, filter strips, permeable paving) scale, tested by ENEA within the GST4Water project ${ }^{4}$.

At the same time, NbS support urban biodiversity, increasing ecological connectivity both within the city and with the surrounding natural and agricultural areas, as highlighted by 
European Commission (2019b), "Relazione della Commissione al Parlamento Europeo, al Consiglio, al Comitato Economico e Sociale Europeo e al Comitato delle Regioni sull'attuazione del piano d'azione per l'economia circolare, 190 final", available at: https://ec.europa.eu/environment/circulareconomy/.

European Commission (2021), "Nature-Based Solutions", available at: https://ec.europa.eu/info/research-and-innovation/research-area/environment/nature-based-solutions_en.

Salvatori, E., Gentile, C., Altieri, A., Aramini, F and Manes, F. (2020), "Nature-Based Solution for reducing $\mathrm{CO}_{2}$ levels in museum environments: a phytoremediation study for the Leonardo da Vinci's "Last Supper"', Sustainability, Vol. 12, pp. 565.

the ENEA research project MaGICLandscapes ${ }^{5}$. In this regard, the use of ecological criteria for the implementation of NbS is fundamental: as a result of the ES-PA project, ENEA has produced guidelines and an operational tool ${ }^{6}$ to create and manage urban green infrastructures in a sustainable way by using native plant species.

Finally, innovative NbS are increasingly applied for the sustainable restoration of cultural heritage, as tested in Matera within the ES-PA Project, as well as for the control of indoor air quality in museum environments (Salvatori et al., 2020).

$\mathrm{NbS}$,therefore, play a key role in ensuring urban sustainability in a global change scenario, as advocated by the SDG 11. The creation of a healthy urban environment has become a priority, as dramatically highlighted by the COVID-19 pandemic, and NbS represent an innovative tool to address societal challenges in this regard. However, in order to fully realise this potential, it is necessary to operationalise the $\mathrm{NbS}$ concept by integrating it into existing policy frameworks as well as with other circular transition tools. In this regard, future project activities should include the active involvement of stakeholders and citizens through participatory decisionmaking processes, in order to highlight $\mathrm{NbS}$ benefits, costs, uncertainties and trade-offs in specific contexts. This represents an essential prerequisite for the implementation of $\mathrm{NbS}$ in cities and territories, in support of an efficient and competitive circular economy.

\section{NOTES}

${ }^{1}$ ICESP website: www.icesp.it

2 Source: https://www.italy-croatia.eu/ web/netwap ${ }^{3}$ Source: http://www.innoweee.eu/it
${ }^{4}$ Source: https://www.gst4water.it/in-
dex.php/il-progetto-offcanvas-new
${ }^{5}$ Source: https://www.interreg-central.
eu/Content.Node/MaGICLandscapes.
html
${ }^{6}$ Source: https://anthosart.florintesa.it/ 